NBER WORKING PAPER SERIES

ANCHORS AWAY: HOW FISCAL POLICY CAN UNDERMINE THE TAYLOR PRINCIPLE

\author{
Eric M. Leeper \\ Working Paper 15514 \\ http://www.nber.org/papers/w15514
}

NATIONAL BUREAU OF ECONOMIC RESEARCH

1050 Massachusetts Avenue

Cambridge, MA 02138

November 2009

Prepared for the Banco Central de Chile's 13th Annual Conference, November 19 and 20, 2009. I thank Todd Walker for many insightful conversations. The views expressed herein are those of the author(s) and do not necessarily reflect the views of the National Bureau of Economic Research.

NBER working papers are circulated for discussion and comment purposes. They have not been peerreviewed or been subject to the review by the NBER Board of Directors that accompanies official NBER publications.

(C) 2009 by Eric M. Leeper. All rights reserved. Short sections of text, not to exceed two paragraphs, may be quoted without explicit permission provided that full credit, including $\odot$ notice, is given to the source. 
Anchors Away: How Fiscal Policy Can Undermine the Taylor Principle

Eric M. Leeper

NBER Working Paper No. 15514

November 2009

JEL No. E31,E52,E62

\begin{abstract}
$\underline{\text { ABSTRACT }}$
Slow moving demographics are aging populations around the world and pushing many countries into an extended period of heightened fiscal stress. In some countries, taxes alone cannot or likely will not fully fund projected pension and health care expenditures. If economic agents place sufficient probability on the economy hitting its "fiscal limit" at some point in the future--after which further tax revenues are not forthcoming--it may no longer be possible for monetary policy behavior that obeys the Taylor principle to control inflation or anchor inflation expectations. In the period leading up to the fiscal limit, the more aggressively that monetary policy leans against inflationary winds, the more expected inflation becomes unhinged from the inflation target. Problems confronting monetary policy are exacerbated when policy institutions leave fiscal objectives and targets unspecified and, therefore, fiscal expectations unanchored. In light of this theory, the paper contrasts monetary-fiscal policy frameworks in the United States and Chile.
\end{abstract}

Eric M. Leeper

Department of Economics

304 Wylie Hall

Indiana University

Bloomington, IN 47405

and NBER

eleeper@indiana.edu 


\title{
Anchors Away: How Fiscal Policy Can Undermine the Taylor Principle*
}

\author{
Eric M. Leeper ${ }^{\dagger}$
}

November 9, 2009

\section{INTRODUCTION}

Policymakers have long understood that if fiscal policy runs amuck and monetary policy is forced to raise seigniorage revenues, big inflations result. Latin American policymakers understand this outcome better than most. This message is implicit in Cagan's (1956) initial study of hyperinflation and the message is explicit in Sargent and Wallace's (1981) theoretical analysis of how monetary policy can lose control of inflation and Sargent's (1983) interpretation of historical episodes of high inflations. The message is forcefully promulgated by international economic organizations that prescribe policy reforms to troubled economies. Underlying this view is the notion that if central bankers display sufficient resolve and stick to their inflation-fighting guns, fiscal policy will eventually relent and reform. Unfortunately, wishing it were so does not make it so.

Recent research on monetary and fiscal policies has learned that the ways in which policies interact to determine inflation and influence the real economy are far more subtle than the "monetization of debt" perspective implies. For example, Sargent and Wallace's (1975) early finding that if the central bank pegs the nominal interest rate - or more generally does not adjust the rate strongly with inflation - then the equilibrium inflation rate is undetermined, is not robust to alternative assumptions about fiscal behavior: Leeper (1991) and others have shown that if primary surpluses are unresponsive to the state of government debt, then inflation is uniquely determined. This is not merely of academic interest. Central banks do go through periods when they adjust interest rates weakly to inflation and many banks are now, in effect, pegging the nominal rate near the zero lower bound. If such behavior endangered price stability by not pinning down the inflation process, this would be of great practical concern.

Another example that has received much attention is that when a government issues nominal debt denominated in its home currency, it is possible for fluctuations in current or

${ }^{*}$ November 9, 2009. Prepared for the Banco Central de Chile's $13^{\text {th }}$ Annual Conference, November 19 and 20, 2009. I thank Todd Walker for many insightful conversations.

${ }^{\dagger}$ Indiana University and NBER, eleeper@indiana.edu. 
expected primary surpluses to generate important aggregate demand effects. ${ }^{1}$ Policies that set the nominal interest rate independently of inflation and primary surpluses independently of outstanding debt represent the canonical case in which a debt-financed tax cut today, which does not carry with it an expectation of higher taxes in the future, raises household wealth and increases aggregate demand. In the standard models used for policy analysis, higher demand raises both output and inflation; higher inflation serves to revalue outstanding nominal debt. Debt revaluation can be an important source of fiscal financing by ensuring that this mix of policies is sustainable.

This canonical case also points to circumstances in which monetary policy can no longer control inflation. Some observers dismiss the case as special, preferring to stick to the convention that fiscal policy is Ricardian in the sense that expansions in debt are always backed by higher expected primary surpluses [McCallum (2001)]. Unfortunately, as I shall argue, demographic, political, and economics realities in many countries may not conform to this conventional view.

Within the class of new Keynesian models now in wide use for monetary policy analysis, something of a consensus has developed around what constitutes "good" monetary policy behavior. In terms of implementable simple rules - as opposed to, say, Ramsey optimal solutions - a necessary condition is that the central bank adjust the nominal interest rate more than one-for-one with inflation; this is called the "Taylor principle" [Taylor (1993)]. This principle seems to produce nearly optimal outcomes in models now in use at central banks [see, for example, Henderson and McKibbin (1993), Rotemberg and Woodford (1997, 1999), Schmitt-Grohé and Uribe (2007), and papers in Taylor (1999b)].

In this paper I explore how the Taylor principle characterization of "good" monetary policy fares in periods of heightened fiscal stress. Fiscal stress is what Chile, the United States, much of Europe, Japan, and a great many other countries are facing in the coming decades as their populations age and government transfer payments for pensions and health care are anticipated to rise substantially as a share of GDP.

It is unlikely that tax revenues alone can finance these promised transfers. Some countries are already at or near the peaks of their Laffer curves, according to some estimates [Trabandt and Uhlig (2009)]. In those countries, it may be economically impossible to raise sufficient revenues. Other countries - with the United States as the leading example - seem to have little tolerance for high tax rates and may find it politically impossible to raise taxes enough. In either scenario, these countries could easily reach their fiscal limits well before the "generational storm" - in Kotlikoff and Burns's (2004) memorable phrase - has fully played out. At its fiscal limit, a government can no longer follow the conventional prescription by which fiscal policy takes care of itself - and everything else that affects the value of government debt - by financing government debt entirely through future surpluses. By extension, the fiscal limit makes it infeasible for monetary policy to always obey the Taylor principle, for doing so results in unsustainable policies.

At the fiscal limit, macro policies enter a new realm that economists have only begun to study systematically. Once taxes can no longer adjust and government purchases have achieved their socially acceptable lower bound, only two sources of fiscal financing remain:

\footnotetext{
${ }^{1}$ The list of contributors to this literature is long, but some key papers include Leeper (1991, 1993), Woodford (1994, 1995), Sims (1994, 2005), Cochrane (1999, 2001), Leith and Wren-Lewis (2000), SchmittGrohé and Uribe (2000), Daniel (2001), and Corsetti and Maćkowiak (2006).
} 
incomplete honoring of promised transfers and surprise revaluations of outstanding nominal government bonds or some combination of both. ${ }^{2}$ The first option would permit monetary policy to continue to follow a Taylor principle because, in effect, actual transfers are adjusting to finance government debt. But the same demographics that are behind the growing transfers payments also create powerful political pressures for democratic governments to honor their earlier promises. The second option allows the government to fully honor its financial commitments, but requires the central bank to give up control of inflation. A more likely outcome is some mix of the two options, possibly with policy fluctuating between the two distinct monetary-fiscal regimes. With the mixed outcome, monetary policy would still lose control of inflation, as Davig and Leeper (2006b, 2009), Chung, Davig, and Leeper (2007), and Davig, Leeper, and Walker (2009) show.

No government has made it completely clear to its populace how the coming fiscal storm will be weathered. Existing rules governing fiscal behavior, where they exist, are not obviously robust to an environment in which government transfers constitute a growing fraction of GDP. And how such fiscal rules interact with, say, an inflation-targeting monetary policy is not well understood. Some large countries, like Germany, the United Kingdom, and the United States, seem to have made no provisions whatsoever for dealing with future fiscal stresses. In those countries, the public has no choice but to speculate about how future policies will adjust. How can expectations of inflation and interest rates be anchored by monetary policy in this new policy realm? What will determine such expectations if not monetary policy? How does the public's speculation about future policy adjustments affect the equilibrium today?

1.1 Anchoring Expectations There is much ballyhoo about how a major benefit of having central banks adopt an explicit inflation target is that it contributes in important ways to anchoring private expectations of inflation. There are as many definitions of "anchoring expectations" as there are people repeating the mantra. Faust and Henderson (2004) grapple with the definition in their thoughtful piece about best-practice monetary policy. Many of their concerns spring from the fact that central banks - even inflation targeters - have multiple objectives and face tradeoffs among those objectives. For our purposes, we simplify the problem by positing that the central bank targets only inflation at $\pi^{*}$ and the tax authority targets only government debt at $b^{*}$. Faust and Henderson correctly observe that if the primary objective of inflation targeting is to anchor long-run expectations of inflation, then formally this amounts to ensuring that $\lim _{j \rightarrow \infty} E_{t} \pi_{t+j}=\pi^{*}$. But by this definition of anchoring, as Faust and Henderson point out, best-practice monetary policy permits $\left|E_{t} \pi_{t+j}-\pi^{*}\right|>\varepsilon>0$ for all $j \geq 0$ : at times, expected inflation over any forecast horizon will be very far from target.

No inflation-targeting central bank embraces such a liberal definition of anchoring expectations. The Central Bank of Chile aims "to keep annual CPI inflation around 3\% most of the time" [Banco Central de Chile (2007)]. Sveriges Riksbank targets 2 percent in Sweden

\footnotetext{
${ }^{2}$ I take off the table two other options: sovereign debt default and pure inflation taxes. It is difficult to imagine an equilibrium in which many large countries default simultaneously, though this possibility deserves further research. Pure inflation taxes are removed on the grounds that historical experience with hyperinflations has found them to be an extraordinarily costly means of fiscal financing. Moreover, like income taxes, inflation taxes are also subject to a Laffer curve and, therefore, a fiscal limit.
} 
[Sveriges Riksbank (2008)]. Both Chile and Sweden have a tolerance range of plus or minus 1 percentage point. In New Zealand, the Reserve Bank targets CPI inflation between 1 and 3 percent [Reserve Bank of New Zealand (2008)]. It is not apparent from their web pages, but I imagine that all inflation-targeting central banks would interpret "long run" to be something shy of infinity. I also imagine that if in those economies expected inflation could drift arbitrarily far from target for arbitrarily long periods, the central banks would not feel that they have successfully anchored long-run inflation expectations (even if one could prove that the Faust-Henderson limiting condition for expected inflation held). Analogous ranges tend to be applied in ministries of finance and treasuries that have an explicit target for government debt [see, for example, New Zealand Treasury (2009), Swedish Ministry of Finance (2008)].

In this paper I shall adopt the more pragmatic notion of anchored expectations that policy authorities seem to apply. If in an equilibrium, expectations of a policy target variable can deviate widely from target for an extended period, then expectations are not well anchored on the announced targets.

1.2 What the Theory SAys I lay out three very simple theoretical models to make concrete the issues that arise in an environment where taxes have reached their limit, but government transfers grow relentlessly. The theory suggests that even if economic agents know how policies will adjust once the economy hits the fiscal limit, it may no longer be possible for monetary policy to achieve its inflation target. ${ }^{3}$ Monetary policy's loss of control of inflation begins well before the fiscal limit is hit. Because agents know such a limit exists, monetary policy cannot control inflation even in the period leading up to the limit when monetary policy dutifully follows the Taylor principle and fiscal policy systematically raises taxes to stabilize debt.

The central bank's problems controlling inflation become more profound in the arguably more plausible environment where agents are uncertain about how monetary and fiscal policies will adjust in the future once the fiscal limit is reached. In such a setting it is easy to see how expectations can become unanchored, particularly if monetary and fiscal authorities do little to help resolve uncertainty about future policies.

Policy uncertainty almost certainly reduces welfare. Existing work tends to model the uncertainty in rather stylized forms - a stochastic capital tax, for example - but nonetheless finds that greater uncertainty reduces growth and welfare [Hopenhayn (1996) and Aizenman and Marion (1993)]. Uncertainty can also generate an option value for waiting to investment, which slows growth [Bernanke (1983), Dixit (1989), and Pindyck (1988)]. Indeed, one argument for having central banks announce their intended interest rate paths is to reduce uncertainty about monetary policy and better anchor expectations and improve the effectiveness of monetary policy [Faust and Leeper (2005), Rudebusch and Williams (2006), and Svensson (2006)]. While the implications of uncertainty for welfare are important, I do not pursue them in the positive analysis that follows.

\footnotetext{
${ }^{3}$ Sims (2005) makes closely related points in the context of inflation targeting. Sims (2009) explains that as an application of Wallace's (1981) Modigliani-Miller theorem for open-market operations, many of the extraordinary measures that central banks have taken over the past year or so run the risk of being insufficiently backed by fiscal policy and, therefore, may make it difficult for monetary policy alone to anchor inflation.
} 
In light of the profound policy uncertainty that many countries will soon face, I find myself in sympathy with North (1990, p. 83): "The major role of institutions in a society is to reduce uncertainty by establishing a stable (but not necessarily efficient) structure to human interaction. The overall stability of an institutional framework makes complex exchange possible across both time and space." Only the policy institutions themselvesvia the desires of the electorate - can help to resolve the uncertainty and only by reducing uncertainty can policy institutions hope to anchor expectations reliably.

After deriving theoretical results, the paper turns to contrast the monetary-fiscal policy frameworks in Chile and the United States. Whereas Chile has adopted specific objectives and even rules for the conduct of monetary and fiscal policy, America has consistently eschewed rules-based policies. Chile's policies contribute toward keeping the economy well away from the fiscal limit, permitting Banco Central de Chile to target inflation and anchor expectations of inflation. In contrast, in the United States, agents have good reason to be concerned that taxes may reach the fiscal limit, undermining the Federal Reserve's ability to control inflation now and in the future.

\section{Three Simple Models}

I present three models of price-level and inflation determination that increase in the subtlety of the interactions between monetary and fiscal policies. Throughout the analysis I restrict attention to rational expectations equilibria, so the results I present can be readily contrasted to prevailing views, which also are based on rational expectations.

The first model draws from Leeper (1991), Sims (1994), and Woodford (2001) to lay the groundwork for how monetary and fiscal policies jointly determine equilibrium. These results are well known, but the broader implications of thinking about macro policies jointly are not fully appreciated. A second model adds one layer of subtlety by positing that at some known date in the future, call it $T$, the economy will reach its fiscal limit, at which point it is not possible to raise further revenues. At that limit, policy regime-the mix of monetary and fiscal rules - changes in some known way. This model illustrates how expectations of future policies can feed back to affect the current equilibrium. The final model adds one more layer of subtlety: although agents know regime will change at date $T$, they are uncertain what mix of monetary and fiscal policies will be realized. In the third model, agents' expectations of inflation depend on the subjective probabilities they attach to possible future policies. The last two models draw on work in Davig, Leeper, and Walker (2009).

The models illustrate how interactions between monetary and fiscal policies, the possibility of regime changes, and uncertainty about future regimes create difficulties for policy authorities who aim to anchor private expectations on the targets of policy.

Each model has a common specification of the behavior of the private sector. An infinitely lived representative household is endowed each period with a constant quantity of nonstorable goods, $y$. To keep the focus away from seigniorage considerations, we examine a cashless economy, which can be obtained by making the role of fiat currency infinitesimally small. Government issues nominal one-period bonds, allowing us to define the price level, $P$, as the rate at which bonds exchange for goods. 
The household chooses sequences of consumption and bonds, $\left\{c_{t}, B_{t}\right\}$, to maximize

$$
E_{0} \sum_{t=0}^{\infty} \beta^{t} u\left(c_{t}\right), \quad 0<\beta<1
$$

subject to the budget constraint

$$
c_{t}+\frac{B_{t}}{P_{t}}+\tau_{t}=y+z_{t}+\frac{R_{t-1} B_{t-1}}{P_{t}}
$$

taking prices and $R_{-1} B_{-1}>0$ as given. The household pays taxes, $\tau_{t}$, and receives transfers, $z_{t}$, each period, both of which are lump sum.

Government spending is zero each period, so the government chooses sequences of taxes, transfers, and debt to satisfy its flow constraint

$$
\frac{B_{t}}{P_{t}}+\tau_{t}=z_{t}+\frac{R_{t-1} B_{t-1}}{P_{t}}
$$

given $R_{-1} B_{-1}>0$, while the monetary authority chooses a sequence for the nominal interest rate.

After imposing goods market clearing, $c_{t}=y$ for $t \geq 0$, the household's consumption Euler equation reduces to the simple Fisher relation

$$
\frac{1}{R_{t}}=\beta E_{t}\left(\frac{P_{t}}{P_{t+1}}\right)
$$

The exogenous (fixed) gross real interest rate, $1 / \beta$, makes the analysis easier but is not without some lose of generality, as Davig, Leeper, and Walker (2009) show in the context of fiscal financing in a model with nominal rigidities. This is less the case in a small open economy, so one interpretation of this model is that it is a small open economy in which government debt is denominated in terms of the home nominal bonds ("currency") and all debt is held by domestic agents.

2.1 Model 1 I begin with simple fixed policy regimes in order to solidify the understanding of how monetary and fiscal policies jointly determine the equilibrium price level and inflation rate. The focus on price-level determination is entirely for analytical convenience; it is not a statement that inflation is the only thing macro policy authority do or should care about. Because price-level determination is the first step toward understanding how macro policies affect the aggregate economies, the key insights I derive from this model extend to more complex environments.

2.1.1 Active Monetary/Passive Tax Policy This model reiterates well-known results about how inflation is determined in the canonical model of monetary policy, as presented in textbooks by Galí (2008) and Woodford (2003), for example. This regime - denoted active monetary and passive fiscal policy - combines an interest rate rule in which the central bank aggressively adjusts the nominal rate in response to current inflation with a tax rule in which the tax authority adjusts taxes in response to government debt sufficiently to stabilize 
debt. ${ }^{4}$ In this textbook, best-of-all-possible worlds, monetary policy can consistently hit its inflation target and fiscal policy can achieve its target for the real value of debt.

To derive the equilibrium price level for the model laid out above, we need to specify rules for monetary, tax, and transfers policies. Monetary policy follows a conventional interest rate rule, which for analytical convenience, is written somewhat unconventionally in terms of the inverse of the nominal interest and inflation rates

$$
R_{t}^{-1}=R^{-1}+\alpha\left(\frac{P_{t-1}}{P_{t}}-\frac{1}{\pi^{*}}\right), \quad \alpha>1 / \beta
$$

where $\pi^{*}$ is the inflation target and $R=\pi^{*} / \beta$ is the steady state nominal interest rate. The condition on the policy parameter $\alpha$ ensures that monetary policy is sufficiently hawkish in response to fluctuations in inflation that it can stabilize inflation around $\pi^{*}$.

Fiscal policy adjusts taxes passively to the state of government debt

$$
\tau_{t}=\tau^{*}+\gamma\left(\frac{B_{t-1}}{P_{t-1}}-b^{*}\right), \quad \gamma>r=1 / \beta-1
$$

where $b^{*}$ is the debt target, $\tau^{*}$ is the steady state level of taxes, and $r=1 / \beta-1$ is the net real interest rate. Imposing that $\gamma$ exceeds the net real interest rate guarantees that any increase in government debt creates an expectation that future taxes will rise by enough to both service the higher debt and retire it back to $b^{*}$.

For now we shall assume that government transfers evolve exogenously according to the stochastic process

$$
z_{t}=(1-\rho) z^{*}+\rho z_{t-1}+\varepsilon_{t}, \quad 0<\rho<1
$$

where $z^{*}$ is steady-state transfers and $\varepsilon_{t}$ is a serially uncorrelated shock with $E_{t} \varepsilon_{t+1}=0$.

Equilibrium inflation is obtained by combining (4) and (5) to yield the difference equation

$$
\frac{\beta}{\alpha} E_{t}\left(\frac{P_{t}}{P_{t+1}}-\frac{1}{\pi^{*}}\right)=\frac{P_{t-1}}{P_{t}}-\frac{1}{\pi^{*}}
$$

Aggressive reactions of monetary policy to inflation imply that $\beta / \alpha<1$ and the unique bounded solution for inflation is

$$
\pi_{t}=\pi^{*}
$$

so equilibrium inflation is always on target, as is expected inflation. ${ }^{5}$

\footnotetext{
${ }^{4}$ Applying Leeper's (1991) definitions, "active" monetary policy targets inflation, while "passive" monetary policy weakly adjusts the nominal interest rate in response to inflation; "active" tax policy sets the tax rate independently of government debt and "passive" tax policy changes rates strongly enough when debt rises to stabilize the debt-GDP ratio; "active" transfers policy makes realized transfers equal promised transfers, while "passive" transfers policy allows realized transfers to be less than promised.

${ }^{5}$ As Cochrane (2007) emphasizes, echoing Obstfeld and Rogoff (1983), there are actually a continuum of explosive solutions to (8), each one associated with the central bank threatening to drive inflation to positive or negative infinity if the private sector's expectations are not anchored on $\pi^{*}$. Cochrane uses this logic to argue that fundamentally only fiscal policy can uniquely determine inflation. Pure theory cannot guide us to the unique solution in (9), but common sense can. Suppose that (5) is not a complete description of policy behavior in all states of the world and that there is a component to policy that says if the economy goes off on an explosive path, monetary policy will change its behavior appropriately to push the economy back to $\pi^{*}$. If that extra component of policy is credible, agents will know that long-run expectations of inflation other than $\pi^{*}$ are inconsistent with equilibrium and, therefore, cannot be rational expectations. In this paper, I sidestep this dispute and simply accept the conventional assertion that we are interested in the unique bounded solution in (9).
} 
If monetary policy determines inflation - and the path of the price level, $\left\{P_{t}\right\}$ - how must fiscal policy respond to disturbances in transfers to ensure that policy is sustainable? This is where passive tax adjustments step in. Substituting the tax rule, (6), into the government's budget constraint, (3), taking expectations conditional on information at $t-1$, and employing the Fisher relation, (4), yields the expected evolution of real debt

$$
E_{t-1}\left(\frac{B_{t}}{P_{t}}-b^{*}\right)=E_{t-1}\left(z_{t}-z^{*}\right)+\left(\beta^{-1}-\gamma\right)\left(\frac{B_{t-1}}{P_{t-1}}-b^{*}\right)
$$

Because $\beta^{-1}-\gamma<1$, higher debt brings forth the expectation of higher taxes, so (10) describes how debt is expected to return to steady state following a shock to $z_{t}$. In a steady state in which $\varepsilon_{t} \equiv 0$, debt is $b^{*}=\left(\tau^{*}-z^{*}\right) /\left(\beta^{-1}-1\right)$, equal to the present value of primary surpluses.

Another perspective on the fiscal financing requirements when monetary policy is targeting inflation emerges from a ubiquitous equilibrium condition. In any dynamic model with rational agents, government debt derives its value from its anticipated backing. In this model, that anticipated backing comes from tax revenues net of transfer payments, $\tau_{t}-z_{t}$. The value of government debt can be obtained by imposing equilibrium on the government's flow constraint, taking conditional expectations, and "solving forward" to arrive at

$$
\frac{B_{t}}{P_{t}}=E_{t} \sum_{j=1}^{\infty} \beta^{j}\left(\tau_{t+j}-z_{t+j}\right)
$$

This equilibrium condition provides a new perspective on the crux of passive tax policy. Because $P_{t}$ is nailed down by monetary policy and $\left\{z_{t+j}\right\}_{j=1}^{\infty}$ is being set independently of both monetary and tax policies, any increase in transfers at $t$, which is financed by new sales of $B_{t}$, must generate an expectation that taxes will rise in the future by exactly enough to support the higher value of $B_{t} / P_{t}$.

In this model, the only potential source of an expansion in debt is disturbances to transfers. But passive tax policy implies that this pattern of fiscal adjustment must occur regardless of the reason that $B_{t}$ increases: economic downturns that automatically reduce taxes and raise transfers, changes in household portfolio behavior, changes in government spending, or central bank open-market operations. To expand on the last example, we could modify this model to include money to allow us to imagine that the central bank decides to tighten monetary policy exogenously at $t$ by conducting an open-market sale of bonds. If monetary policy is active, then the monetary contraction both raises $B_{t}$-bonds held by households - and it lowers $P_{t}$; real debt rises from both effects. This can be an equilibrium only if fiscal policy is expected to support it by passively raising future tax revenues. Refusal by tax policy to adjust appropriately undermines the ability of open-market operations to affect inflation in the conventional manner. ${ }^{6}$

\footnotetext{
${ }^{6}$ This is an application of the general insight contained in Wallace (1981). Sargent and Wallace's "Unpleasant Monetarist Arithmetic" (1981) outcome emerges because the tax authority refuses to respond "appropriately," forcing monetary policy in the future to abandon its inflation target. Tobin (1980) emphasizes the distinct consequences for household's portfolios of "normal" central bank operations, such as open-market operations, and helicopter drops of money. Section 2.2 picks up this theme.
} 
A policy regime in which monetary policy is active and tax policy is passive produces the conventional outcome that inflation is always and everywhere a monetary phenomenon and a hawkish central bank can successfully anchor actual and expected inflation at the inflation target. Tax policy must support the active monetary behavior by passively adjusting taxes to finance disturbances to government debt - from whatever source, including monetary policy - and ensure policy is sustainable.

Although conventional, this regime is not the only mechanism by which monetary and fiscal policy can jointly deliver a unique bounded equilibrium. We turn now to the other polar case.

2.1.2 Passive Monetary/Active Tax Policy Passive tax behavior is a stringent requirement: the tax authority must be willing and able to raise taxes in the face of rising government debt. For a variety of reasons, this does not always happen, and it certainly does not happen in the automated way prescribed by the tax rule in (6). Sometimes political factors - such as the desire to seek reelection - prevent taxes from rising as needed to stabilize debt. ${ }^{7}$ Some countries simply do not have the fiscal infrastructure in place to generate the necessary tax revenues. Others might be at or near the peak of their Laffer curves, suggesting they are close to the fiscal limit. ${ }^{8}$ In this case, tax policy is active and $0 \leq \gamma<1 / \beta-1$.

Analogously, there are also periods when the concerns of monetary policy move away from inflation stabilization and toward other matters, such as output stabilization or financial crises. These are periods in which monetary policy is no longer active, instead adjusting the nominal interest rate only weakly in response to inflation. The global recession and financial crisis of 2007-2009 is a striking case when central banks' concerns shifted away from inflation. Then monetary policy is passive and, in terms of the policy rule, $(5), 0 \leq \alpha<1 / \beta .{ }^{9}$

We focus on a particular policy mix that yields clean economic interpretations: the nominal interest rate is set independently of inflation, $\alpha=0$ and $R_{t}^{-1}=R^{-1}$, and taxes are set independently of debt, $\gamma=0$ and $\tau_{t}=\tau^{*}$. These policy specifications might seem extreme and special, but the qualitative points that emerge generalize to other specifications of passive monetary/active tax policies.

One result pops out immediately. Applying the pegged nominal interest rate policy to the Fisher relation, (4) yields

$$
E_{t}\left(\frac{P_{t}}{P_{t+1}}\right)=\frac{1}{\beta R}=\frac{1}{\pi^{*}}
$$

so expected inflation is anchored on the inflation target, an outcome that is perfectly consistent with one aim of inflation-targeting central banks. It turns out, however, that another aim of inflation targeters - stabilization of actual inflation - which can be achieved by active monetary/passive fiscal policy, is no longer attainable.

\footnotetext{
${ }^{7}$ Davig and Leeper (2006b, 2009) generalize (6) to estimate Markov switching rules for the United States and find that tax policy has switched between periods when tax rise with debt and periods when it does not.

${ }^{8}$ Trabandt and Uhlig (2009) characterize Laffer curves for capital and labor taxes in 14 EU countries and the United States to find that some countries - Denmark and Sweden - are on the wrong side of the curve, suggesting that must lower tax rates to raise revenues.

${ }^{9}$ Davig and Leeper $(2006 \mathrm{~b}, 2009)$ provide evidence of this for the United States and Davig and Leeper (2007) study the nature of equilibria when monetary policy regularly switches between being active and being passive.
} 
Impose the active tax rule on the intertemporal equilibrium condition, (IEC),

$$
\frac{B_{t}}{P_{t}}=\left(\frac{\beta}{1-\beta}\right) \tau^{*}-E_{t} \sum_{j=1}^{\infty} \beta^{j} z_{t+j}
$$

and use the government's flow constraint, (3), to solve for the price level

$$
P_{t}=\frac{R_{t-1} B_{t-1}}{\left(\frac{1}{1-\beta}\right) \tau^{*}-E_{t} \sum_{j=0}^{\infty} \beta^{j} z_{t+j}}
$$

At time $t$, the numerator of this expression is predetermined, representing the nominal value of household wealth carried into period $t$. The denominator is the expected present value of primary fiscal surpluses from date $t$ on, which is exogenous. So long as $R_{t-1} B_{t-1}>0$ and the present value of revenues exceeds the present value of transfers, a condition that must hold if government debt has positive value, expression (13) delivers a unique $P_{t}>0$.

We have done nothing mystical here, despite what some critics claim [for example, Buiter (2002) or McCallum (2001)]. In particular, the government is not assumed to behave in a manner that violates its budget constraint. Unlike competitive households, the government is not required to choose sequences of control variables that are consist with its budget constraint for all possible price sequences. Indeed, for a central bank to target inflation, it cannot be choosing its policy instrument to be consistent with any sequence of the price level; doing so would produce an indeterminate equilibrium. Identical reasoning applies to the fiscal authority: the value of a dollar of debt- $1 / P_{t}$ - depends on expectations about fiscal decisions in the future; expectations, in turn, are determined by the tax rule the fiscal authority announces. The fiscal authority credibly commits to its tax rule and, given the process for transfers, this determines the backing of government debt and, therefore, its market value. ${ }^{10}$

As remarkable as it may seem, using the solution for the price level in (13) to compute expected inflation, it is straightforward to show that $\beta E_{t}\left(P_{t} / P_{t+1}\right)=1 / R$, as required by the Fisher relation and monetary policy behavior. ${ }^{11}$ This observation leads to a sharp dichotomy between the roles of monetary and fiscal policy in price-level determination: monetary policy alone appears to determine expected inflation by choosing the level at which to peg the nominal interest rate, $R^{-1}$, while conditional on that choice, fiscal variables appear to determine realized inflation.

To understand the nature of this equilibrium, we need to delve into the underlying economic behavior. This is an environment in which changes in debt do not elicit any changes in expected taxes, unlike in section 2.1.1. First consider a one-off increase in current transfer payments, $z_{t}$, financed by new debt issuance, $B_{t}$. With no offsetting increase in current or

\footnotetext{
${ }^{10}$ Cochrane (2001) refers to the intertemporal equilibrium condition, (IEC) or (24), as a "debt valuation equation," and reasons that government debt gets valued analogously to equities.

${ }^{11}$ To see this, compute

$$
E_{t-1} \frac{1}{P_{t}}=\frac{\left(\frac{1}{1-\beta}\right) \tau^{*}-E_{t-1} \sum_{j=0}^{\infty} \beta^{j} z_{t+j}}{R_{t-1} B_{t-1}}
$$

To find expected inflation, simply use the date $t-1$ version of (13) for $P_{t-1}$ and simplify to obtain $\beta E_{t}\left(P_{t} / P_{t+1}\right)=1 / R_{t-1}=1 / R$.
} 
expected tax obligations, households feel wealthier and they try to shift up their consumption paths. Higher demand for goods drives up the price level, and continues to do so until the wealth effect dissipates and households are content with their initial consumption plan. This is why in expression (24) the value of debt at $t$ changes with expected, but not current, transfers. Now imagine that at time $t$ households receive news of higher transfers in the future. There is no change in nominal debt at $t$, but there is still an increase in household wealth. Through the same mechanism, $P_{t}$ must rise to revalue current debt to be consistent with the new expected path of transfers.

Cochrane (2009, p. 5) offers another interpretation of the equilibrium in which "aggregate demand' is really just the mirror image of demand for government debt." An expectation that transfers will rise in the future reduces the household's assessment of the value of government debt. Households can shed debt only by converting it into demand for consumption goods, hence the increase in aggregate demand that translates into a higher price level.

Expression (13) highlights that in this policy regime the impacts of monetary policy change dramatically. When the central bank chooses a higher rate at which to peg the nominal interest rate, the effect is to raise the price level next period. This echos Sargent and Wallace (1981), but the economic mechanism is different. In the current policy mix, a higher nominal interest rate raises the interest payments the household receives on the government bonds it holds. Higher $R_{t-1} B_{t-1}$, with no higher anticipated taxes raises household wealth, triggering the same adjustments as above. In this sense, as in Sargent and Wallace, monetary policy has lost control of inflation.

This section has reviewed existing results on price-level determination under alternative monetary-fiscal policy regimes. In each regime the price level is uniquely determined, but the impacts of changes in policy differ markedly across the two regimes. We now apply the notion that there is a fiscal limit to create a natural setting that blends the two regimes just considered.

2.2 Model 2 The second model adds a layer of subtlety to the analysis in sections 2.1.1 and 2.1.2. We take seriously the notion that there exists a limit to the degree of taxation a society will tolerate by imposing that at some known date in the future, $T$, taxes have reached this maximum allowable level, $\tau^{\max }{ }^{12}$ Leading up to $T$, policy is in the active monetary/passive fiscal regime described above, but from date $T$ on, tax policy has no option but to become active, with $\tau_{t}=\tau^{\max }$ for $t \geq T$. If monetary policy remained active, neither authority would stabilize debt and debt would explode. Existence of equilibrium requires that monetary policy switch to being passive, which stabilizes debt. ${ }^{13}$ Table 1 summarizes the assumptions about policy behavior.

To solve for this equilibrium we break the intertemporal equilibrium condition into two

\footnotetext{
${ }^{12}$ In this model with lump-sum taxes there is no upper bound for taxes or debt, so long as debt does not grow faster than the real interest rate. But in a more plausible production economy, in which taxes distort behavior, there would be a natural fiscal limit. See Davig, Leeper, and Walker (2009) for further discussion and Bi (2009) for an application of an endogenous fiscal limit to the issue of sovereign debt default.

${ }^{13}$ Monetary policy is forced to switch because we assume that the fiscal limit is an absorbing state. Davig and Leeper (2009) display an equilibrium in which passive fiscal policy is a recurring state, so that it is feasible for both policies to be active simultaneously, as least temporarily.
} 


\begin{tabular}{l|c|c} 
& $\begin{array}{c}\text { Regime } 1 \\
t=0,1, \ldots, T-1\end{array}$ & $\begin{array}{c}\text { Regime } 2 \\
t=T, T+1, \ldots\end{array}$ \\
\hline Monetary Policy & $R_{t}^{-1}=R^{-1}+\alpha\left(\frac{P_{t-1}}{P_{t}}-\frac{1}{\pi^{*}}\right)$ & $R_{t}^{-1}=R^{-1}$ \\
Tax Policy & $\tau_{t}=\tau^{*}+\gamma\left(\frac{B_{t-1}}{P_{t-1}}-b^{*}\right)$ & $\tau_{t}=\tau^{\max }$
\end{tabular}

Table 1: Monetary-Fiscal Policy Regimes Before and After the Fiscal Limit at Date $T$

parts

$$
\frac{B_{0}}{P_{0}}=E_{0} \sum_{j=1}^{T-1} \beta^{j} s_{j}+E_{0} \sum_{j=T}^{\infty} \beta^{j} s_{j}
$$

where the function for the primary surplus, $s_{t}$, changes at the fiscal limit

$$
s_{t}= \begin{cases}\tau^{*}-\gamma\left(B_{t-1} / P_{t-1}-b^{*}\right)-z_{t}, & t=0,1, \ldots, T-1 \\ \tau^{\max }-z_{t}, & t=T, \ldots, \infty\end{cases}
$$

Expression (14) decomposes the value of government debt at the initial date into the expected present value of surpluses leading up to the fiscal limit and the expected present value of surpluses after the limit has been hit.

Evaluating the second part of (14), after the limit is hit at $T$

$$
\begin{aligned}
E_{0}\left(\frac{B_{T-1}}{P_{T-1}}\right) & =E_{0} \sum_{j=1}^{\infty} \beta^{j} s_{T-1+j} \\
& =\beta\left\{\frac{\tau^{\max }}{1-\beta}-\frac{z_{0} \rho^{T}}{1-\beta \rho}\right\}
\end{aligned}
$$

The first part of (14) is a bit messier, as it involves solving out for the endogenous taxes that are responding to the state of government debt before the fiscal limit is hit. For any $1<N \leq T$, we have

$$
\begin{aligned}
E_{0} \frac{B_{T-N}}{P_{T-N}} & =E_{0} \sum_{j=1}^{\infty} \beta^{j} s_{T-N+j} \\
& =\beta E_{0}\left(s_{T-(N-1)}\right)+\beta^{2} E_{0}\left(s_{T-(N-2)}\right)+\cdots+\beta^{N-1} E_{0}\left(s_{T-1}\right)+\beta^{N-T} E_{0} \sum_{j=T}^{\infty} \beta^{j} s_{j}
\end{aligned}
$$

After substituting for the tax rule and the transfers process, the expected value of debt at any period before the fiscal limit is

$$
\begin{aligned}
E_{0} \frac{B_{T-N}}{P_{T-N}} & =\frac{\beta}{1-\gamma \beta}\left(\left(\tau-\gamma b^{*}\right)\left(1+\beta+\beta^{2}+\cdots+\beta^{N-2}\right)\right. \\
& \left.-z_{0}\left(\rho^{T-(N-1)}+\beta \rho^{T-(N-2)}+\beta^{2} \rho^{T-(N-3)}+\cdots+\beta^{N-2} \rho^{T-1}\right)\right)+\frac{\beta^{N-1}}{1-\gamma \beta} E_{0} \frac{B_{T-1}}{P_{T-1}}
\end{aligned}
$$


Combining (16) and (17) yields the value of debt in period $t=0$

$$
\frac{B_{0}}{P_{0}}=\frac{1}{1-\gamma \beta}\left(\left(\tau-\gamma b^{*}\right)\left(\beta+\beta^{2}+\cdots+\beta^{T-1}\right)+\beta^{T} \frac{\tau^{\max }}{1-\beta}-z_{0} \frac{\rho \beta}{1-\rho \beta}\right)
$$

This expression determines the equilibrium value of debt. The value of debt at $t=0$ - and by extension at each date in the future - is uniquely determined by parameters describing preferences and fiscal behavior and by the exogenous realization of transfers at that date. We arrive at this expression by substituting out the endogenous sequence of taxes before the fiscal limit. Apparently this economy will not exhibit Ricardian equivalence even if tax policy obeys a rule that raises taxes to retire debt back to steady state. This occurs despite the fact that in the absence of a fiscal limit such a tax rule delivers Ricardian equivalence, as it did in section 2.1.1.

Two other implications are immediate. Higher transfers at time $0, z_{0}$, which portend a higher future path of transfers because of their positive serial correlation, reduce the value of debt. This occurs for the reasons that section 2.1.2 lays out: higher expected government expenditures reduce the backing and, therefore, the value of government liabilities. A second immediate implication is more surprising. How aggressively tax policy responds to debt before hitting the fiscal limit, as parameterized by $\gamma$, matters for the value of debt. Permanent active monetary/passive tax policies, in contrast, produce Ricardian equivalence in this model, so the timing of taxation is irrelevant: how rapidly taxes stabilize debt has no bearing on the value of debt. Both of these unusual implications are manifestations of the breakdown in Ricardian equivalence that occurs when there is the prospect that at some point the economy will hit a fiscal limit, beyond which taxes will no longer adjust to finance debt. ${ }^{14}$

I now turn to how the equilibrium price level is determined. Given $B_{0} / P_{0}$ from (18) and calling the right side of (18) $b_{0}$, use the government's flow budget constraint at $t=0$ and the fact that $s_{0}=\tau_{0}-z_{0}$, with taxes following the rule shown in table 1 to solve for $P_{0}$ :

$$
P_{0}=\frac{R_{-1} B_{-1}}{b_{0}+\tau_{0}-z_{0}}
$$

Given $R_{-1} B_{-1}>0$, (19) yields a unique $P_{0}>0$ if $b_{0}+\tau_{0}-z_{0}>0$, which it must if government debt is valued. Entire sequences of equilibrium $\left\{P_{t}, R_{t}^{-1}\right\}_{t=0}^{\infty}$ are solved recursively: having solved for $B_{0} / P_{0}$ and $P_{0}$, obtain $R_{0}$ from the monetary policy rule in table 1 , and derive the nomimal value of debt. Then use (18) redated at $t=1$ to obtain equilibrium $B_{1} / P_{1}$ and the government budget constraint at $t=1$ to solve for $P_{1}$ using (19) redated at $t=1$, and so forth.

The equilibrium price level has the same features as it does under the passive monetary/active tax regime in section 2.1.2. Higher current or expected transfers, which are not backed in present-value terms by expected taxes, raise household wealth, increase demand

\footnotetext{
${ }^{14}$ This is not to suggest that one cannot cook up "Ricardian scenarios." For example, because $T$ is known, if the government were to commit to fully finance the change in the present value of transfers that arises from a shock to $z_{0}$ before the economy reaches the fiscal limit, one could obtain a Ricardian outcome. But this is driven by the fact that $T$ is known. If $T$ were uncertain, as in Davig, Leeper, and Walker (2009), with some probability of occurring at every date, even this cooked-up scenario would not produce a Ricardian result.
} 
for goods, and drive up the price level (reducing the value of debt). A higher pegged nominal interest rate raises nominal interest payments, raising wealth and the price level next period. Similarities between this equilibrium and that in section 2.1.2 stem from the fact that price-level determination is driven by beliefs about policy in the long run. From $T$ on, this economy is identical to the fixed-regime passive monetary/active fiscal policies economy and it is beliefs about long-run policies that determine the price level. Of course, before the fiscal limit the two economies are quite different and the behavior of the price level will also be different.

In this environment where the equilibrium price level is determined entirely by fiscal considerations through its interest rate policy, monetary policy determines the expected inflation rate. Combining (4) with (5) we obtain an expression in expected inflation

$$
E_{t}\left(\frac{P_{t}}{P_{t+1}}-\frac{1}{\pi^{*}}\right)=\frac{\alpha}{\beta}\left(\frac{P_{t-1}}{P_{t}}-\frac{1}{\pi^{*}}\right)
$$

where monetary policy behaves as table 1 specifies.

As argued above, the equilibrium price level sequence, $\left\{P_{t}\right\}_{t=0}^{\infty}$ is determined by versions of (18) and (19) for each date $t$, so (20) describes the evolution of expected inflation. Given equilibrium $P_{0}$ from (19) and an arbitrary $P_{-1}$ - arbitrary because the economy starts at $t=0$ and cannot possibly determine $P_{-1}$, regardless of policy behavior-(20) shows that $E_{0}\left(P_{0} / P_{1}\right)$ grows relative to the initial inflation rate. In fact, throughout the active monetary policy/passive fiscal policy phase, for $t=0,1, \ldots, T-1$, expected inflation grows at the rate $\alpha \beta^{-1}>1$. In periods $t \geq T$ monetary policy pegs the nominal interest rate at $R$, and expected inflation is constant: $E_{t}\left(P_{t} / P_{t+1}\right)=(R \beta)^{-1}=1 / \pi^{*}$.

The implications of the equilibrium laid out in equations (18), (19), and (20) for government debt, inflation, and the anchoring of expectations on the target values $\left(b^{*}, \pi^{*}\right)$ are most clearly seen in a simulation of the equilibrium. Figure 1 contrasts the paths of the debt-GDP ratio from two models: the fixed passive monetary/active tax regime in section 2.1.2 - dashed line - and the present model in which an active monetary/passive tax regime is in place until the economy hits the fiscal limit at date $T$, when policies switch permanently to a passive monetary/active tax combination - solid line. ${ }^{15}$

The fixed regime displays stable fluctuations of real debt around the 50 percent steady state debt-GDP, which, of course, the other model also produces once it hits the fiscal limit. Leading up to the fiscal limit, however, it is clear that the active monetary/passive tax policy combination does not keep debt near target. Expected inflation evolves according to (20). Evidently, since leading up the fiscal limit monetary policy is active, with $\alpha>1 / \beta$, there is no tendency for expected inflation to be anchored on the inflation target. Figure 2 plots the inverse of inflation from the fixed-regime model in section 2.1.2 - dashed line - and from the present model - solid line - along with expected (inverse) inflation from the present modeldotted dashed line. Inflation in the fixed regime fluctuates around $1 / \pi^{*}$ and, of course, with the pegged nominal interest rate, expected inflation is anchored on target. But in the period leading up to the fiscal limit, the price level is being determined primarily by fluctuations in

\footnotetext{
${ }^{15}$ Figures 1 through 4 use the following calibration. Leading up to the fiscal limit, $\alpha=1.50$ and $\gamma=0.20$ and at the limit and in the fixed-regime model, $\alpha=\gamma=0.0$. We assume steady state values $\tau^{*}=0.19$, $z^{*}=0.17, \pi^{*}=1.02$ (gross inflation rate) and we assume $1 / \beta=1.04$ so that $b^{*}=0.50$. The transfers process has $\rho=0.90$ and $\sigma=0.003$. Identical realizations of transfers were used in all the figures.
} 


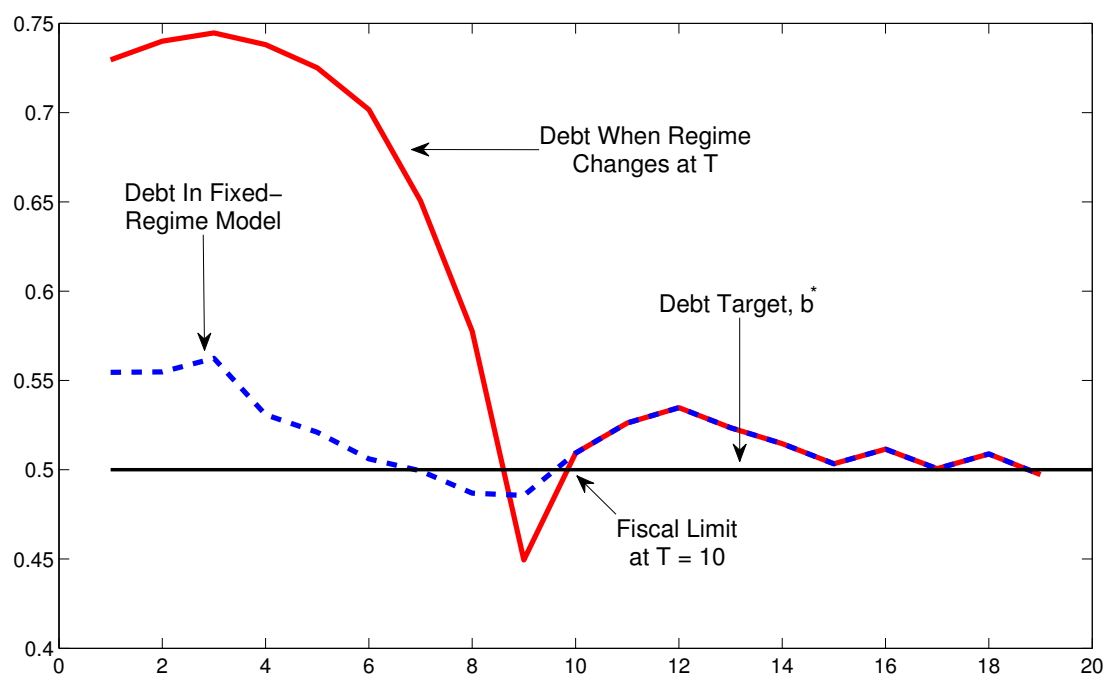

Figure 1: Debt-GDP ratios for a particular realization of transfers for two models: the fixed passive monetary/active tax regime in section 2.1.2 - dashed line - and the present model in which an active monetary/passive tax regime is in place until the economy hits the fiscal limit at date $T$, when policy switch permanently to a passive monetary/active tax combination - solid line.

the real value of debt, which as figure 1 shows, deviates wildly from $b^{*}$. Expected inflation in that period, though not independent of the inflation target, is certainly not anchored by the target. Instead, under active monetary policy, the deviation of expected inflation from target grows with the deviation of actual inflation from target in the previous period. The figure shows how equation (20) makes expected inflation follow actual inflation, with active monetary policy amplifying movements in expected inflation.

The result for periods $t=0,1, \ldots, T-1$ is reminiscent of Loyo's (1999) analysis of Brazilian monetary-fiscal interactions in the 1980s. Throughout the 1970s Brazilian tax policy was active and monetary policy was passive. Inflation, interest rates, and primary deficits were stable. In 1980, partly in response to pressure from international organizations, Brazilian monetary policy switched to being active. Doubly active policies is essentially what is going on in the model above because the knowledge that taxes will hit their limit at time $T$ prevents expected surpluses from that period on from adjusting to satisfy the intertemporal equilibrium condition. In Brazil, when monetary policy switched to being active, with no corresponding switch in fiscal policy to being passive, inflation and interest rates began to grow rapidly, even though there was no change in seigniorage revenues. Loyo's analysis reverses the ordering of this model, with passive monetary/active fiscal policy before $T$, and doubly active policies after.

To underscore the extent to which inflation is unhinged from monetary policy, even in the active monetary/passive tax regime before the fiscal limit, figures 3 and 4 repeat the previous figures, but make the response of the passive tax policy to debt weaker ( $\gamma$ is reduced to 0.1 from 0.2). As might be expected, when taxes respond more weakly to debt, the debt run- 


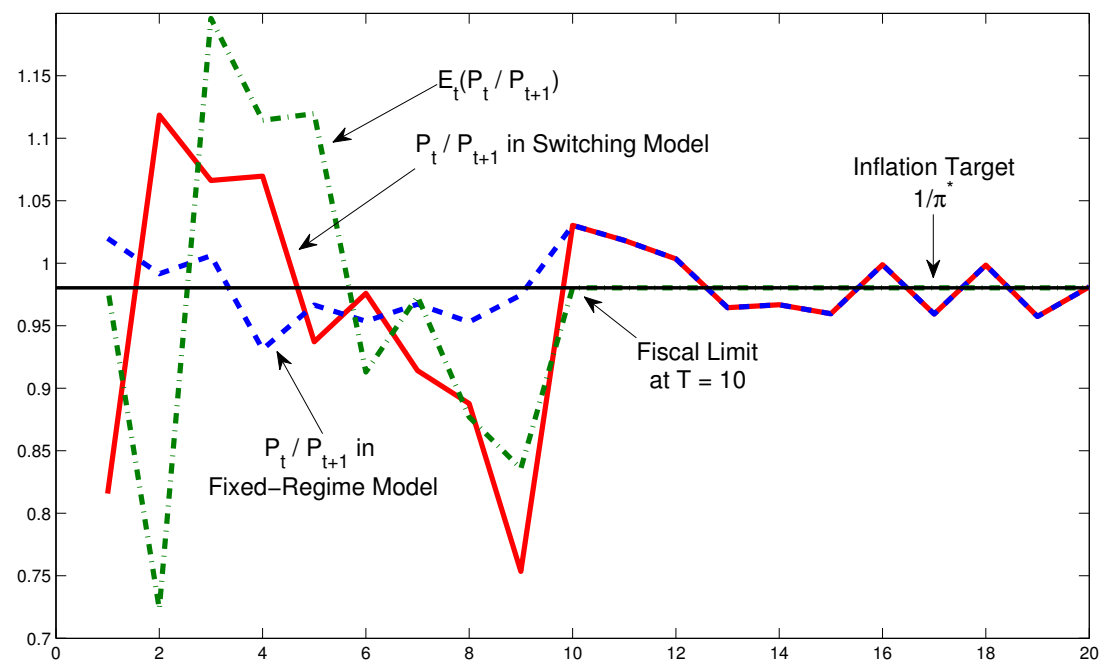

Figure 2: Inverse of inflation for a particular realization of transfers for two models: the fixed passive monetary/active tax regime in section 2.1.2 - dashed line - and the present model in which an active monetary/passive tax regime is in place until the economy hits the fiscal limit at date $T$, when policy switch permanently to a passive monetary/active tax combination - solid line; expectation of inverse inflation from present model- dotted dashed line.

up that appears in figure 1 is amplified in the period leading ip to the fiscal limit. More surprising, the change in the tax rule dramatically alters the inflation and expected inflation processes, even in a regime, that were it expected to last forever, would exhibit Ricardian equivalence.

Because monetary policy loses control of inflation after the fiscal limit it reached, forwardlooking behavior implies it also loses control of inflation before the fiscal limit is hit. By extension, changes in fiscal behavior in the period leading up to the limit affects both the equilibrium inflation process and the process for expected inflation.

2.3 Model 3 The two models presented above contain no uncertainty about future policy regime, making the rather implausible - though extremely common - assumption that agents know exactly what monetary and fiscal policies will be in effect at every date in the future. Although this assumption is maintained in nearly all macro studies, it is difficult to reconcile the assumption with observed policy behavior. In fact, policies do change and, therefore, they can change. In the face of a history of changes in policy regimes, analyses that fail to incorporate the possibility of regime change into expectations formation run the risk of misspecifying expectations and providing misleading policy advice. ${ }^{16}$ Given the prominent role ascribed to expectations formation in policy discussions and deliberations, this is a potentially serious misspecification of policy models.

\footnotetext{
${ }^{16}$ This is the theme of Cooley, LeRoy, and Raymon (1982, 1984), Sims (1982, 1987), Andolfatto and Gomme (2003), Leeper and Zha (2003), Davig (2004), Davig and Leeper (2006b,a, 2007, 2009), Chung, Davig, and Leeper (2007), and Davig, Leeper, and Walker (2009).
} 


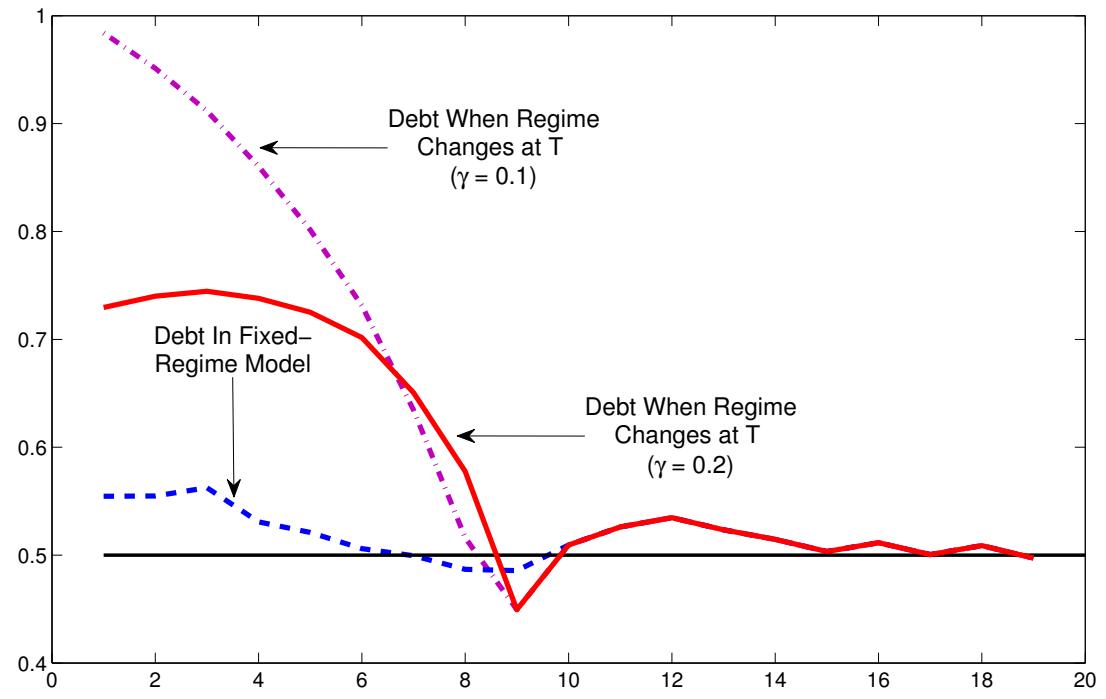

Figure 3: Repeats figure 1 and adds debt-GDP in the active monetary/passive tax regime before the economy hits the fiscal limit at date $T$, when the response of taxes to debt is weaker $(\gamma=0.1)$ - dotted dashed line.

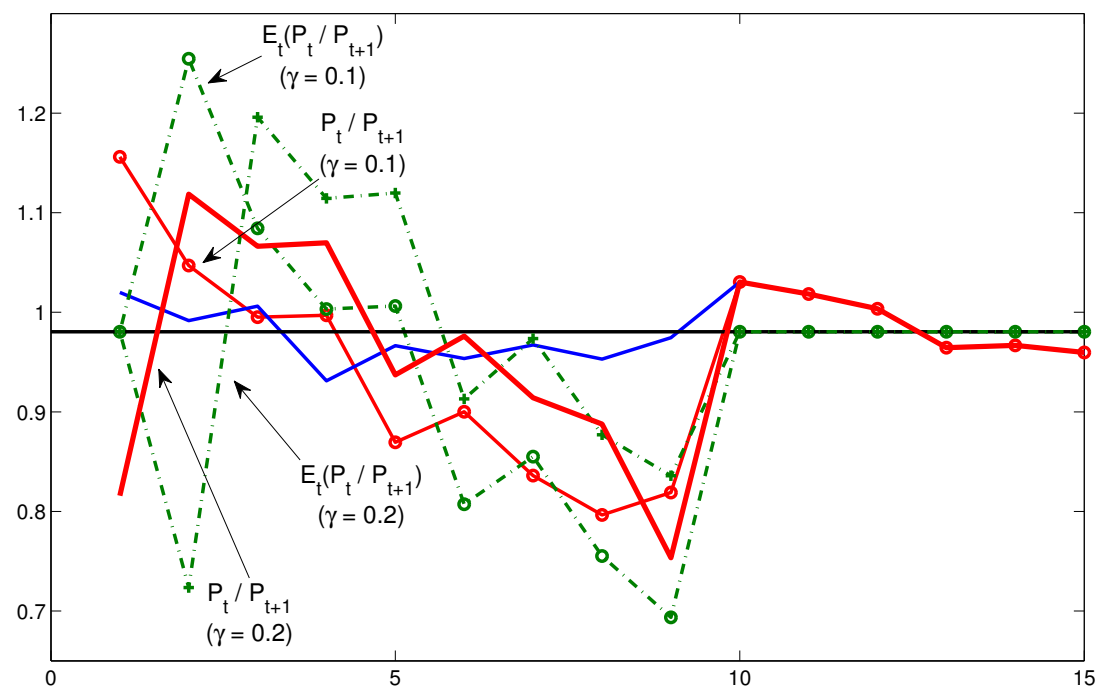

Figure 4: Repeats figure 2 and adds inverse of inflation - solid line with circles - and expectation of inverse of inflation - dotted dashed line with circle - in the active monetary/passive tax regime before the economy hits the fiscal limit at date $T$, when the response of taxes to debt is weaker $(\gamma=0.1)$. 
I introduce uncertainty about policy in a stark fashion that allows me to extract some implications of policy uncertainty while retaining analytical tractability. The economy continues to hit the fiscal limit at a known date $T$, at which point taxes become active, setting $\tau_{t}=\tau^{\max }$ for all $t \geq T$. Uncertainty arises because at the limit agents place probability $q$ on a regime that combines passive monetary policy with active transfers policy and probability $1-q$ on a regime with active monetary policy and passive transfers policy. In polite company, passive transfers policy is referred to as "entitlements reform." 17 To avoid the tangle of euphemisms, I refer to this as "reneging on promised transfers." Instead of receiving promised transfers of $z_{t}$ at time $t$, agents receive $\lambda_{t} z_{t}$, with $\lambda_{t} \in[0,1]$, so $\lambda_{t}$ is the fraction of promised transfers that the government honors. Budget constraints for the household and the government, equations (2) and (3), are modified to replace $z_{t}$ with $\lambda_{t} z_{t}$.

Aging populations in many countries represent a looming fiscal crisis that offers a practical motivation for considering the possibility that governments may not honor their promises. Some countries-Australia, Chile, New Zealand, Norway, Sweden-are preparing for the demographic shifts through the creation of superannuation funds or the adoption of fiscal rules that aim to have surpluses that can be saved to meet future government obligations. Other countries - Germany, the United Kingdom, the United States - are entering the period of enhanced fiscal stress unprepared. In both sets of countries there is uncertainty about exactly how the government will finance its obligations, but in the unprepared countries, government reneging on promised transfers is a real possibility. This possibility potentially has important impacts on expectations formation and economic decisions today.

For simplicity we reduce the previous models to just three periods. In the initial two period $(t=0,1)$, the fiscal limit has not been reached, promised transfers follow the process in (7), monetary policy is active and tax policy is passive. The economy begins with $R_{-1} B_{-1}>$ 0 given and some arbitrary $P_{-1}$. This is equivalent to the time period $t=0, \ldots, T-1$ in section 2.2. At the beginning of period two $(t=2)$, the fiscal limit is reached but agents remain uncertain about which mix of policies will be adopted. This uncertainty is resolved at the end of period 2. In period 3, there is no uncertainty about policy and therefore, period 3 is completely analogous to section 2.2 for $t=T, T+1, \ldots$

Combining the Fisher relation, (4), with the active monetary policy rule, (5), for periods 0 and 1 yields

$$
E_{0}\left(\frac{P_{1}}{P_{2}}-\frac{1}{\pi^{*}}\right)=\frac{\alpha^{2}}{\beta^{2}}\left(\frac{P_{-1}}{P_{0}}-\frac{1}{\pi^{*}}\right)
$$

and combining the government budget constraint, (3), with the passive tax rule, (6), yields

$$
E_{0}\left(\frac{B_{1}}{P_{1}}-b^{*}\right)=E_{0}\left(z_{1}-z^{*}\right)+\left(\beta^{-1}-\gamma\right)\left(\frac{B_{0}}{P_{0}}-b^{*}\right)
$$

Agents know that in the next period $(t=2)$ the fiscal limit will be reached and policy will switch to either a passive monetary/active transfers regime with probability $q$, or an

\footnotetext{
${ }^{17}$ To quote the New York Times, "Just about everybody agrees that solving the deficit depends on reducing the benefits that current law has promised to retirees, via Medicare and Social Security. That's not how people usually put it, of course. They tend to use the more soothing phrase 'entitlement reform.' But entitlement reform is just another way of saying that we can't pay more in benefits than we collect in taxes" [Leonhardt (2009)].
} 
active monetary/passive transfers regime with probability $(1-q)$. Assume that the reneging rate is fixed and known at $t=0$, so $\lambda_{2}=\lambda_{3}=\lambda \in[0,1]$. Then the conditional probability distribution of these policies is given by

$$
\left\{\begin{array}{lll}
q & R_{2}^{-1}=R^{-1}, & z_{2}=\rho z_{1}+\varepsilon_{2} \\
(1-q) & R_{2}^{-1}=R^{-1}+\alpha\left(\frac{P_{1}}{P_{2}}-\frac{1}{\pi^{*}}\right), & \lambda z_{2}=\lambda \rho z_{1}+\lambda \varepsilon_{2}
\end{array}\right.
$$

The analogs of (21) and (22) for period 2 are

$$
\begin{gathered}
E_{2}\left(\frac{P_{2}}{P_{3}}-\frac{1}{\pi^{*}}\right)=(1-q) \frac{\alpha}{\beta}\left(\frac{P_{1}}{P_{2}}-\frac{1}{\pi^{*}}\right) \\
E_{1}\left(\frac{B_{2}}{P_{2}}-b^{*}\right)=[q+(1-q) \lambda] E_{1} z_{2}-z^{*}+\beta^{-1}\left(\frac{B_{1}}{P_{1}}-b^{*}\right)
\end{gathered}
$$

In (24), to make the relationships transparent, I have imposed that $\tau^{\max }=\tau^{*}$, the steady state level of taxes.

In period $3, \tau_{3}$ is set to completely retire debt $\left(B_{3}=0\right)$ no matter which policy regime is realized in period 2. This corresponds to $\tau_{3}=\delta z_{3}+\left(R_{2} B_{2}\right) / P_{3}$, where $\delta=1$ if the economy is in the passive monetary/active transfers regime and $\delta=\lambda$ if the active monetary/passive transfer regime is realized. This assumption implies that agents know one period in advance which tax policy will be in place in the final period.

Combining (21) and (23), we obtain a relationship between expected inflation between periods 2 and 3 and actual inflation in the initial period

$$
E_{0}\left(\frac{P_{2}}{P_{3}}-\frac{1}{\pi^{*}}\right)=(1-q) \frac{\alpha^{3}}{\beta^{3}}\left(\frac{P_{-1}}{P_{0}}-\frac{1}{\pi^{*}}\right)
$$

Given the discount rate $\beta$, this solution for expected inflation shows that whether expected inflation converges to target or drifts from target depends on the probability of switching to passive monetary/active transfers policies relative to how hawkishly monetary policy targets inflation when it is active. For the deviation of expected inflation from target to be smaller than the deviation of actual inflation from target in period $t=0$, we need $q>1-(\beta / \alpha)^{3}$. The longer the period leading up to the fiscal limit, the larger must $q$ be to ensure that (25) is stable. It may seem paradoxical, but the more hawkish is policy-larger $\alpha$-the greater must be the probability that monetary policy will be passive ("dovish?") in the future in order for the evolution of expected inflation to be stable. Resolution of this paradox comes from recognizing that when $q=1$, so monetary policy is known to be passive at the fiscal limit, expected inflation is anchored on $\pi^{*}$, whereas when $q=0$, so transfers policy is known to be passive at the limit, then (25) yields equilibrium inflation, just as in section 2.1.1.

Since we assume that taxes in period 3 are known, and they are a function of exogenous objects, we can treat $\tau_{3}$ as fixed. Combining (22) and (24) and imposing that $B_{3}=0$, as is the debt target in the last period,

$$
\frac{B_{0}}{P_{0}}-b^{*}=\left(\frac{1}{\beta^{-1}-\gamma}\right) E_{0}\left\{\beta^{2}\left\{\left(\tau_{3}-\tau^{*}\right)-\left(\vartheta z_{3}-z^{*}\right)\right]-\beta\left(\vartheta z_{2}-z^{*}\right)-\left(z_{1}-z^{*}\right)\right.
$$

where $\vartheta=q+(1-q) \lambda$ determines expected post-reneging transfers. 
Equation (26) uniquely determines the value of debt in period 0 as a function of the expected present value of surpluses. We can combine (26) with the government's flow constraint at $t=0$ to obtain a unique expression for $P_{0}$ as a function of $R_{-1} B_{-1}, \tau_{0}, z_{0}$, and the parameters in the expression for equilibrium $B_{0} / P_{0}$.

The solution in (26) leads to the following inferences. As $q$ - the probability of switching to the passive monetary/active transfers regime - rises, the value of debt at 0 falls, and $P_{0}$ rises. In addition, as $\lambda$-the fraction of transfers on which the government reneges in periods 2 and 3 -falls, the value of debt at 0 falls, and the price level rises. Both of the consequences for $P_{0}$ operate through standard fiscal theory wealth effects. Higher $q$ means there is less likelihood that the government will renege, so expected transfers and, therefore, household wealth rise. Households attempt to convert the higher wealth into consumption goods, driving up the price level until real wealth falls sufficiently that they are content to consume their original consumption place. Lower $\lambda$ also raises the expected value of transfers, increasing wealth and the price level.

Expectational effects associated with switching policies can be seen explicitly in (25) and (26). Equation (26) shows that the value of debt is still determined by the discounted expected value of net surpluses. In contrast to the previous models without uncertainty about future policies, now the actual surplus is conditional on the realized policy regime. Conditional on time $t=0$ information, the expected transfers process in periods 2 and 3 is unknown. If $q \in(0,1)$ and at the end of period two passive monetary policy is realized, agents will be "surprised" by amount $z_{2}(1-q)(1-\lambda)$ in period 2 and by amount $z_{3}(1-q)(1-\lambda)$ in period 3. With transfers surprisingly high-because the passive transfers regime with reneging was not realized-households feel wealthier and try to convert that wealth into consumption. This drives up the price level in periods 2 and 3, revaluing debt downward. This surprise acts as an innovation to the agent's information set due to policy uncertainty. Naturally, as agents put high probability on this regime occurring $(q \approx 1)$ or assumes the amount of reneging is small $\left(\lambda_{2}, \lambda_{3} \approx 1\right)$, the surprise is also small, and vice versa.

Comparing (25) with (20), expected inflation in period 1 now depends on $q$, which summarizes beliefs about future policies. This is true even though the monetary policy regime is active in period 1 . The previous model demonstrated that monetary policy alone cannot determine the price level. With policy uncertainty, monetary policy alone cannot determine expected inflation. If agents put high probability on the passive monetary/active transfers regime $(q \approx 1)$, then expected inflation at the beginning of period 2 will be primarily pinned down by the nominal peg. This result is irrespective of the actual policy regime announced at the end of period 2. It is in this sense that expectational effects about policy uncertainty can dramatically alter equilibrium outcomes.

In this simple setup, these expectational effects are limited in magnitude because agents know precisely when the fiscal limit is reached. The additional level of uncertainty not examined in these simple models, but present in Davig, Leeper, and Walker (2009), is randomness in when tax policy will hit the the fiscal limit. In that environment, the conditional probability of switching policies outlined above would contain an additional term specifying the conditional probability of hitting the fiscal limit in that period. This implies that, because there is positive probability of hitting the fiscal limit in every period up to $T$, these expectational effects will be present from $t=0, \ldots, T$ and will gradually become more important as the probability of hitting the fiscal limit increases. In effect, the endogenous probability 
of hitting the fiscal limit makes the probability $q$ time varying.

2.4 Summary The models presented above severely understate the degree of uncertainty about future policies that private agents face in actual economies. To derive a rational expectations equilibrium, I have taken stands on the stochastic structure of the economy that are difficult to reconcile with observations about any actual policy environment. ${ }^{18}$

Remarkably, the models show that even in a setting that drastically understates the actual degree of uncertainty, private expectations of monetary and fiscal objectives are not well anchored on the targets of policy. These models also make clear that in an economy that faces heightened fiscal stress, the monetary policy behavior that most economists regard as "good" cannot control either actual or expected inflation. "Good" monetary policy can actually exaggerate the swings in expected inflation.

\section{Policy Institutions and Future Policies}

This section examines monetary and fiscal policy arrangements in Chile and the United States to draw some inferences about how the theoretical points derived above might play out in those economies. Chile and America offer interesting contrasts. Whereas Chile has adopted specific objectives and even rules for the conduct of monetary and fiscal policy, America has eschewed rules-based policies. Banco Central de Chile is guided by an explicit inflation target; the Federal Reserve operates under a multiple mandate. Chile has adopted a series of fiscal rules, designed in part to provide for its aging population; the United States has done nothing except implement short-run fiscal policies that are projected to double the outstanding debt over the next decade. For the theme of this paper-how macro policies do or do not anchor expectations - the contrast is particularly relevant.

3.1 The United States Even in normal times, the multiple objectives that guide Federal Reserve decisions and the absence of any mandates to guide federal tax and spending policies conspire to make it very difficult for private agents to form expectations of monetary and fiscal policies. ${ }^{19}$

In the United States, the Congressional Budget Office (CBO) regularly publishes projections of the country's long-run fiscal situation. In the wake of the financial crisis and recession of 2007-2009, monetary and fiscal policies have not been normal and, as long-term projections by the CBO make plain, in the absence of dramatic policy changes, policies are unlikely to return to normalcy for generations to come. Figure 5 reports actual and CBO projections of federal transfers due to Social Security, Medicaid, and Medicare as a percentage of GDP [Congressional Budget Office (2009)]. Demographic shifts and rising relative costs of health care combine to grow these transfers from under 10 percent of GDP today to about 25 percent in 70 years. One much-discussed consequence of this growth is shown in figure 6, which plots actual and CBO projections of federal government debt as a share of GDP from 1790 to 2083. Relative to the future, the debt run-ups associated with the Civil

\footnotetext{
${ }^{18}$ Sargent (2006) acknowledges this and goes so far as to say that American monetary and fiscal policies are marked by "ambiguity or Knightian uncertainty," which preclude the specificity about stochastic structure assumed in the models of section 2.

${ }^{19}$ This section draws heavily on Leeper (2009) and Davig, Leeper, and Walker (2009).
} 


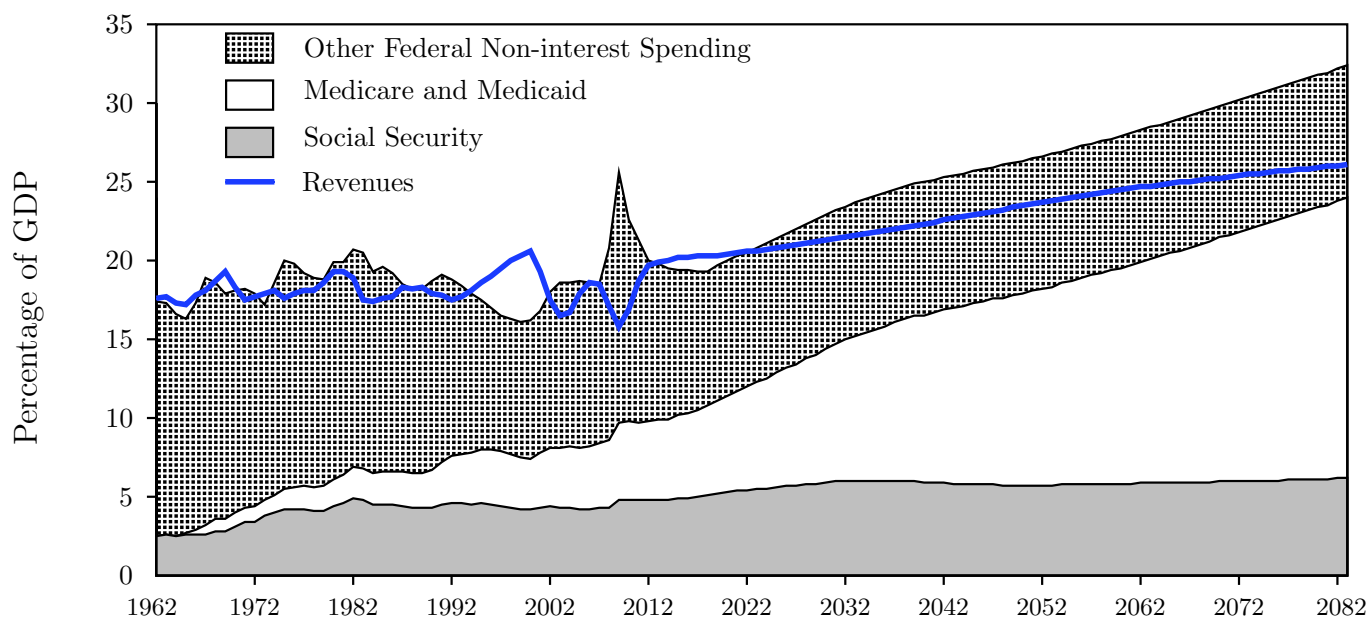

Figure 5: Projected and actual federal expenditures decomposed into Medicare, Medicaid, and Social Security spending and other non-interest spending. The solid line represents actual and projected revenues under the Extended-Baseline scenario, which assumes current law does not change. Source: Congressional Budget Office (2009).

War, World War I, World War II, the Reagan deficits, and the current fiscal stimulus are mere hiccups.

What can be learned from such debt projections? Two things. First, under the maintained assumptions, debt will grow exponentially in these countries. Second, the maintained assumptions - which produced the exploding debt paths - cannot possibly hold. We learn the second point from the intertemporal equilibrium condition. Figure 6 implies that within our children's lifetimes, U.S. debt will exceed the fiscal limit, violating the intertemporal equilibrium condition. ${ }^{20}$ These projections are public information and well understood by investors who continue to buy these government bonds without demanding a risk premium. Why do they continue to buy bonds? Because their expectations of future policy adjustments are at odds with the projections' maintained assumptions. In sum, figures of exploding debt paths, which fiscal authorities around the world routinely publish, arise from economic behavior that is not happening and which flies in the face of basic economic logic. Projections of things that cannot happen cannot help to anchor expectations.

Having the future inherit larger government debt is problematic for several reasons. First, higher debt entails higher debt service and more government expenditures must be devoted to paying interest on outstanding debt. Historically, countries have found that higher debt service crowds out other forms of government expenditures. Second, as the intertemporal equilibrium condition implies, higher debt requires higher present-value surpluses. But that present value is bounded: as a share of GDP, tax revenues have some maximum level and spending has some minimum level. At those levels, the natural fiscal limit is reached and the economy cannot support a value of debt higher than that limit. By pushing more debt

\footnotetext{
${ }^{20}$ The U.S. fiscal limit is unknown, but I imagine it implies something less than a 300 percent debt-GDP ratio.
} 


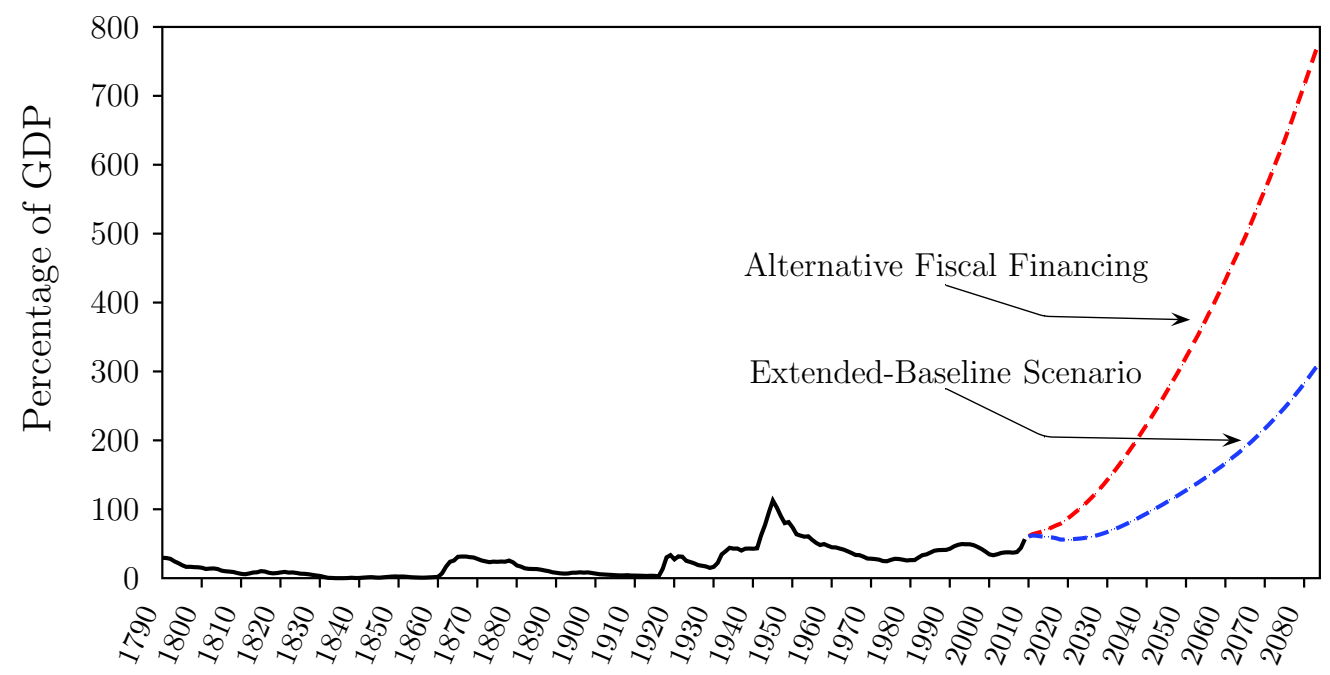

Figure 6: CBO's projections of Debt-to-GDP ratio under Extended-Baseline and Alternative Fiscal Financing Scenarios. Extended-Baseline assumes current law does not change, while Alternative Fiscal Financing allows for "policy changes that are widely expected to occur and that policymakers have regularly made in the past," according to the CBO. Source: Congressional Budget Office (2009).

into the future, current policies move debt closer to the fiscal limit, which places restrictions on fiscal flexibility in the future. But the future is when the fiscal consequences of aging populations come home to roost; it is precisely when fiscal flexibility is most needed.

Additional reasons that higher debt is problematic tie back to anchoring expectations. Higher levels of interest payments require larger future fiscal adjustments. If the public is uncertain about the hows and whys of those adjustments, the macroeconomic consequences of the move to higher debt will be difficult to predict. But there is another more fundamental issue. In countries without guidelines governing debt levels, large debt run-ups leave unanswered a question that is critical to the public's formation of expectations: will the economy settle in at the new, higher level of debt or will policy endeavor to retire debt back to its previous level or some other level? The answer to this question is central to the public's ability to form reasonable fiscal expectations.

And what of Federal Reserve policy? Many observers believe that U.S. monetary policy performance improved dramatically with the appointment of Chairman Paul Volcker in 1979 and continued to be good at least until the most recent period [Taylor (1999a), Clarida, Galí, and Gertler (1999)]. The appointment of a sequence of good Federal Reserve chairs, however, has been largely a matter of luck, rather than a reflection of institutional reform. This institutional reality is underscored by the fact that the particular Fed chair plays such a large role in the outcome of Fed policies. Expectations formation is all the more challenging in this kind of unstructured environment.

3.2 Chile Two linchpins in Chilean macro policies are the mandate that Banco Central de Chile targets a three percent inflation rate (plus or minus a percentage point) and the Fiscal 
Responsibility Law. ${ }^{21}$ The Basic Constitutional Act of the Central Bank of Chile, passed in 1989, granted the central bank full independence and prescribed price stability and smooth functioning of the payments systems as its objectives. A formal inflation target was adopted in 2007, with the aim of hitting three percent inflation "in a medium term horizon of two years." As with many inflation targeting central banks, along with the explicit target came enhanced transparency and an emphasis on communication with the public.

Although many countries adopted inflation targeting without also implementing a compatible fiscal framework, Chile has been at the vanguard of countries that have reformed their monetary and fiscal policy institutions jointly. Chilean fiscal policy has been guided by a structural surplus rule since 2000 and the rule was given some legal teeth by the passage of the Fiscal Responsibility Law in August 2006. In the beginning, the ruled aimed for a structural surplus of 1 percent of GDP. But the target itself is state dependent: it was changed to 0.5 percent in 2008 and since January 2009 it was changed again, explicitly temporarily, to aim to balance the budget.

Like many Latin American countries, Chilean fiscal policy was strongly procyclical, which exacerbated cyclical fluctuations. ${ }^{22}$ The structural balance methodology, and the associated surplus rule, were designed to counter the procyclicality, among several other key goals. To arrive at the structural surplus, the government estimates what revenues it would receive if the economy were growing at trend and the prices of copper and molybdenum were at their long-run levels. ${ }^{23}$ For the first six years the aim of the surplus was to accumulate assets that could be used to meet future government obligations, particularly guaranteed minimum pensions and old-age transfer payments.

Benefits from the adoption of the structural surplus rule have been remarkable. Some key benefits include

1. Chilean fiscal policy has been freed to behave countercyclically.

2. Government debt and interest payments on debt fell through the 2000s, with gross central debt down to 5 percent of GDP in 2008.

3. Establishment of a Pension Reserve Fund whose assets are invested, just as private pension funds are invested, and accumulated to meet future obligations. ${ }^{24}$

4. Sovereign debt interest-rate spreads for Chile are now well below those of other emerging economies and did not rise after 9/11 or the Argentine crisis of 2002, when other countries' spread rose sharply; the decline in Chilean spreads began with the adoption of the structural balance policy.

\footnotetext{
${ }^{21}$ This section draws on several sources, including Perry, Servén, and Suescún (2008), Singh, Belaisch, Collyns, De Masi, Krieger, Meredith, and Rennhack (2005), Rodríguez C., Tokman R., and Vega C. (2007), Marshall (2003), Banco Central de Chile (2007), Velasco (2008), and International Monetary Fund (2009).

${ }^{22}$ Procyclicality and its consequences are documented in Gavin and Perotti (1997) and Kaminsky, Reinhart, and Végh (2004).

${ }^{23}$ Batini, Levine, and Pearlman (2009) and Kumhof and Laxton (2009) assess the performance of such a rule in dynamic stochastic general equilibrium models.

${ }^{24}$ Several countries have similar funds. Norway has created a large sovereign wealth fund from oil revenues; Australia and New Zealand have superannuation funds.
} 
5. Declining sovereign debt risk spreads speak directly to the improved prospects for sustainability of Chile's fiscal policies.

Items 4 and 5 cut on the paper's theme of anchoring expectations and, therefore, deserve elaboration. ${ }^{25}$ Small open economies are susceptible to large external shocks that make the economies highly volatile. This tendency is still more pronounced in economies, like Chile, that are strongly affected by fluctuations in commodity prices. Bi (2009) shows theoretically that default risk premia emerge from the market's expectations about a country's ability and willingness to service its debt. Ability arises endogenously from the country's stochastic fiscal limit, which is tied to the peak of the country's Laffer curve. The probability distribution of the fiscal limit depends on how persistent and volatile technology shocks are, the size of the government, the degree of countercyclicality of fiscal policies, and the impatience of political decisionmakers. Volatile economies tend to have highly dispersed distributions for the fiscal limit, which increase the probability of default at any given debt-GDP ratio; countries with large government transfer programs have fiscal limits with lower means; impatient political leaders reduce the mean of the limit.

A country's willingness to service debt is driven by the flexibility of its fiscal policy. Flexible policy implies a willingness to raise taxes or lower government expenditures in the face of debt run-ups. A country that is operating well below its fiscal limit and is willing to adjust surpluses to stabilize debt, can successfully steer its way through economic downturns without incurring the wrath of financial markets in the form of risk premia.

Viewed in the context of fiscal limits, Chile's structural balance rule and related innovations stemming from Fiscal Responsibility Law serve to move Chile's government debt position farther from the fiscal limit. Greater distance from the limit arises from both reduced government debt today and from effectively shifting the distribution of the limit up to higher debt-GDP levels. Shifts in the distribution of the fiscal limit come from forcing a longer-term perspective on fiscal decisions and by creating reserves that can be tapped in the future to finance benefits to the aging population. In this sense, the structural balance rule contributes in important ways to anchoring expectations on sustainable policies that are well cushioned away from Chile's fiscal limit.

As the theory in this paper implies, so long as the probability of hitting the fiscal limit in Chile is remote, there is every reason to believe that Banco Central de Chile's efforts at inflation targeting will continue to be successful.

\section{Concluding Remarks}

Many countries are entering an extended period of relentless growth in transfer payments promised to their aging populations. Some, but not all, of these countries ultimately are relying on a pay-as-you-go scheme for financing these expenditures. If there is a level of taxation that, for economic or political reasons, those economies cannot exceed, then the pay-as-you-go scheme is unsustainable.

As Herb Stein famously said, "If something cannot go on forever, it will stop." Stein also pointed out that, although economists are good at pointing out when something cannot

${ }^{25}$ This discussion is based on the insightful study of fiscal limits and sovereign debt risk premia by Bi (2009). 
persist indefinitely, they are less adept at predicting when it will stop. True enough in the present context. But we can say something constructive. Economic agents' beliefs about when the economy will reach its fiscal limit and how policies will adjust after the limit will feedback to affect the equilibrium we observe today, before the limit is reached. Predicting when an economy will hit its fiscal limit is less important for policymaking than is the systematic analysis of the possible existence of such a limit and all that that implies about expectations and macro policy effects.

For policymakers, the feedback from beliefs about the limit to the current equilibrium should be disturbing. Because pre-limit economic decisions depend in part of beliefs about post-limit policy behavior, accurate predictions of the impacts of policy changes today rely on understanding to what those beliefs are anchored. Coherent monetary-fiscal frameworks can help to anchor those beliefs. Incoherent frameworks can actually make beliefs even more untethered.

Countries can guard against this eventuality by implementing monetary-fiscal frameworks that keep their debt-GDP ratios well away from their fiscal limits. ${ }^{26}$ But fiscal limits are country specific and depend on myriad things that characterize a country's political-economic environment. No one-size-fits-all policy framework will work across a highly diverse set of countries.

Chile has instituted a monetary-fiscal framework that, at least for now, appears to be moving the country farther from its fiscal limit. With sufficient distance from that limit, there is reason to believe that Banco Central de Chile's pursuit of inflation targeting can successfully anchor actual and expected inflation. Progress has been far slower - or nonexistent - in many larger countries. And even responsible countries may bear some of the costs created by those large countries.

\footnotetext{
${ }^{26}$ Of course, there is a delicate balancing act here, since high tax rates and low government infrastructure spending, which could keep debt low, are also socially costly.
} 


\section{REFERENCES}

Aizenman, J., and N. Marion (1993): "Policy Uncertainty, Persistence and Growth," Review of International Economics, 1(2), 145-163.

Andolfatto, D., And P. Gomme (2003): "Monetary Policy Regimes and Beliefs," International Economic Review, 44(1), 1-30.

Banco Central de Chile (2007): Central Bank of Chile: Monetary Policy in an Inflation Targeting Framework. Banco Central de Chile, Santiago.

Batini, N., P. Levine, and J. Pearlman (2009): "Monetary and Fiscal Rules in an Emerging Small Open Economy," IMF Working Paper WP/09/22.

Bernanke, B. S. (1983): "Irreversibility, Uncertainty, and Cyclical Investment," Quarterly Journal of Economics, 98(1), 85-106.

BI, H. (2009): "Sovereign Risk Premia, Fiscal Limits and Fiscal Policy," Manuscript, Indiana University.

Buiter, W. H. (2002): "The Fiscal Theory of the Price Level: A Critique," Economic Journal, 112(481), 459-480.

Cagan, P. (1956): "The Monetary Dynamics of Hyperinflation," in Studies in the Quantity Theory of Money, ed. by M. Friedman, pp. 25-117. University of Chicago Press, Chicago.

Chung, H., T. Davig, and E. M. Leeper (2007): "Monetary and Fiscal Policy Switching," Journal of Money, Credit and Banking, 39(4), 809-842.

Clarida, R., J. Galí, and M. Gertler (1999): "The Science of Monetary Policy: A New Keynesian Perspective," Journal of Economic Literature, 37(4), 1661-1707.

Cochrane, J. H. (1999): "A Frictionless View of U.S. Inflation," in NBER Macroeconomics Annual 1998, ed. by B. S. Bernanke, and J. J. Rotemberg, vol. 14, pp. 323-384. MIT Press, Cambridge, MA.

(2001): "Long Term Debt and Optimal Policy in the Fiscal Theory of the Price Level," Econometrica, 69(1), 69-116.

- (2007): "Inflation Determination with Taylor Rules: A Critical Review," Manuscript, University of Chicago.

— (2009): "Understanding Fiscal and Monetary Policy in 2008-2009," Manuscript, University of Chicago.

Congressional Budget Office (2009): The Long-Term Budget Outlook. CBO, Washington, D.C., June.

Cooley, T. F., S. F. LeRoy, and N. Raymon (1982): "Modeling Policy Interventions," Manuscript, University of California Santa Barbara. 
$467-470$.

Corsetti, G., And B. MaćKowiak (2006): "Fiscal Imbalances and the Dynamics of Currency Crises," European Economic Review, 50(5), 1317-1338.

DANiEL, B. C. (2001): "The Fiscal Theory of the Price Level in an Open Economy," Journal of Monetary Economics, 48(October), 293-308.

Davig, T. (2004): "Regime-Switching Debt and Taxation," Journal of Monetary Economics, 51(4), 837-859.

Davig, T., And E. M. Leeper (2006a): "Endogenous Monetary Policy Regime Change," in NBER International Seminar on Macroeconomics 2006, ed. by L. Reichlin, and K. D. West, pp. 345-377. MIT Press, Cambridge, MA.

(2006b): "Fluctuating Macro Policies and the Fiscal Theory," in NBER Macroeconomics Annual 2006, ed. by D. Acemoglu, K. Rogoff, and M. Woodford, vol. 21, pp. 247-298. MIT Press, Cambridge.

$607-635$.

(2007): "Generalizing the Taylor Principle," American Economic Review, 97(3),

- (2009): "Monetary-Fiscal Policy Interactions and Fiscal Stimulus," NBER Working Paper No. 15133.

Davig, T., E. M. Leeper, and T. B. Walker (2009): “'Unfunded Laibilities' and Uncertain Fiscal Financing," Manuscript, Indiana University.

Dixit, A. K. (1989): "Entry and Exit Decisions Under Uncertainty," Journal of Political Economy, 97(3), 620-638.

Faust, J., And D. W. Henderson (2004): "Is Inflation Targeting Best-Practice Monetary Policy?," Federal Reserve Bank of St. Louis Economic Review, 86(4), 117-143.

Faust, J., And E. M. Leeper (2005): "Forecasts and Inflation Reports: An Evaluation," Manuscript, Indiana University.

Galí, J. (2008): Monetary Policy, Inflation, and the Business Cycle. Princeton University Press, Princeton.

Gavin, M., and R. Perotti (1997): "Fiscal Policy in Latin America," in NBER Macroeconomics Annual 1997, ed. by B. S. Bernanke, and J. Rotemberg, vol. 12, pp. 11-61. MIT Press, Canbridge, MA.

Henderson, D. W., And W. McKibbin (1993): "An Assessment of Some Basic Monetary Policy Regime Pairs: Analytical and Simulation Results from Simple Multiregion Macroeconomic Models," in Evaluating Policy Regimes: New Research in Empirical Macroeconomics, ed. by R. C. Bryant, P. Hooper, and C. L. Mann. The Brookings Institution, Washington, D.C. 
Hopenhayn, H. (1996): "Policy Variability and Economic Growth," Review of Economic Studies, 63(4), 611-625.

International Monetary Fund (2009): "Chile: Selected Issues," IMF Country Report No. 09/272, September.

Kaminsky, G. L., C. M. Reinhart, and C. A. VÉgh (2004): "When It Rains, It Pours: Procyclical Capital Flows and Macroeconomic Policies," in NBER Macroeconomics Annual 2004, ed. by M. Gertler, and K. Rogoff, vol. 19, pp. 11-53. MIT Press, Cambridge, MA.

Kotlikoff, L. J., And S. Burns (2004): The Coming Generational Storm: What You Need to Know About America's Economic Future. MIT Press, Cambridge, MA.

Kumhof, M., and D. Laxton (2009): "Chile's Structureal Fiscal Surplus Rule: A ModelBased Evaluation," IMF Working Paper WP/09/88.

Leeper, E. M. (1991): “Equilibria Under 'Active' and 'Passive' Monetary and Fiscal Policies," Journal of Monetary Economics, 27(1), 129-147.

- (1993): "The Policy Tango: Toward a Holistic View of Monetary and Fiscal Effects," Federal Reserve Bank of Atlanta Economic Review, 78(4), 1-27.

- (2009): "Anchoring Fiscal Expectations," Reserve Bank of New Zealand Bulletin, $72(3), 7-32$.

Leeper, E. M., And T. Zha (2003): "Modest Policy Interventions," Journal of Monetary Economics, 50(8), 1673-1700.

Leith, C., And S. Wren-Lewis (2000): "Interactions between Monetary and Fiscal Policy Rules," The Economic Journal, 110(462), 93-108.

Leonhardt, D. (2009): "A Drop in the Wrong Bucket," New York Times, October 29.

Loyo, E. (1999): "Tight Money Paradox on the Loose: A Fiscalist Hyperinflation," Manuscript, Harvard University.

Marshall, J. (2003): "Fiscal Rule and Central Bank Issues in Chile," in Fiscal Issues and Central Banking in Emerging Economies, pp. 98-106. Bank for International Settlements, Basel, BIS Papers, No. 20.

McCallum, B. T. (2001): "Indeterminacy, Bubbles, and the Fiscal Theory of Price Level Determination," Journal of Monetary Economics, 47(1), 19-30.

New Zealand Treasury (2009): Fiscal Strategy Report. The Treasury, Wellington, May 28.

North, D. C. (1990): Institutions, Institutional Change, and Economic Performance. Cambridge University Press, Cambridge. 
Obstfeld, M., and K. Rogoff (1983): "Speculative Hyperinflations in Maximizing Models: Can We Rule Them Out?," Journal of Political Economy, 91(August), 675-687.

Perry, G. E., L. Servén, and R. Suescún (eds.) (2008): Fiscal Policy, Stabilization, and Growth: Prudence or Abstinence? The World Bank, Washington, D.C.

Pindyck, R. C. (1988): "Irreversible Investment, Capacity Choice, and the Value of the Firm," American Economic Review, 78(5), 969-985.

Reserve Bank of New Zealand (2008): Policy Targets Agreement. Reserve Bank of New Zealand, Wellington.

Rodríguez C., J., C. Tokman R., and A. Vega C. (2007): "Structural Balance in Chile," OECD Journal on Budgeting, 7(2), 59-92.

Rotemberg, J. J., And M. Woodford (1997): "An Optimization-Based Econometric Framework for the Evaluation of Monetary Policy," in NBER Macroeconomics Annual 1997, ed. by B. S. Bernanke, and J. J. Rotemberg, vol. 12, pp. 297-346. MIT Press, Cambridge, MA.

- (1999): "Interest Rate Rules in an Estimated Sticky Price Model," in Monetary Policy Rules, ed. by J. B. Taylor, pp. 57-119. University of Chicago Press, Chicago.

Rudebusch, G. D., and J. C. Williams (2006): "Revealing the Secrets of the Temple: The Value of Publishing Interest Rate Projections," NBER Working Paper No. 12638, October.

Sargent, T. J. (1983): "The Ends of Four Big Inflations," in Inflation: Causes and Effects, ed. by R. E. Hall, pp. 41-97. University of Chicago Press for the NBER, Chicago.

(2006): "Ambiguity in American Monetary and Fiscal Policy," Japan 85 The World Economy, 18(3), 324-330.

Sargent, T. J., and N. Wallace (1975): "Rational' Expectations, the Optimal Monetary Instrument, and the Optimal Money Supply Rule," Journal of Political Economy, $83,241-254$.

- (1981): "Some Unpleasant Monetarist Arithmetic," Federal Reserve Bank of Minneapolis Quarterly Review, 5(Fall), 1-17.

Schmitt-Grohé, S., and M. Uribe (2000): "Price Level Determinacy and Monetary Policy Under a Balanced-Budget Requirement," Journal of Monetary Economics, 45(February), 211-246.

(2007): "Optimal Simple and Implementable Monetary and Fiscal Rules," Journal of Monetary Economics, 54(6), 1702-1725.

Sims, C. A. (1982): "Policy Analysis with Econometric Models," Brookings Papers on Economic Activity, 1, 107-152. 
(1987): "A Rational Expectations Framework for Short-Run Policy Analysis," in New Approaches to Monetary Economics, ed. by W. A. Barnett, and K. J. Singleton, pp. 293-308. Cambridge University Press, Cambridge, UK.

(1994): "A Simple Model for Study of the Determination of the Price Level and the Interaction of Monetary and Fiscal Policy," Economic Theory, 4(3), 381-399.

(2005): "Limits to Inflation Targeting," in The Inflation-Targeting Debate, ed. by B. S. Bernanke, and M. Woodford, pp. 283-299. The University of Chicago Press, Chicago.

(2009): "Fiscal/Monetary Coordination When the Anchor Cable Has Snapped," Slides, Princeton University, May 22.

Singh, A., A. Belaisch, C. Collyns, P. De Masi, R. Krieger, G. Meredith, and R. Rennhack (2005): "Stabilization and Reform in Latin America: A Macroeconomic Perspective on the Experience Since the Early 1990s," International Monetary Fund Occasional Paper No. 238.

Svensson, L. E. O. (2006): "Social Value of Public Information: Comment: Morris and Shin (2002) Is Actually Pro-Transparency, Not Con," American Economic Review, 96(1), $448-451$.

Sveriges Riksbank (2008): Monetary Policy in Sweden. Sveriges Riksbank, Stockholm.

Swedish Ministry of FinAnCE (2008): Guidelines for Central Government Debt Management 2009. Government Offices of Sweden, Stockholm, http://www.regeringen.se/sb/d/10494/a/115541.

TAYlor, J. B. (1993): "Discretion versus Policy Rules in Practice," Carneige-Rochester Conference Series on Public Policy, 39, 195-214.

(1999a): "An Historical Analysis of Monetary Policy Rules," in Monetary Policy Rules, ed. by J. B. Taylor, pp. 319-341. University of Chicago Press, Chicago.

(ed.) (1999b): Monetary Policy Rules. University of Chicago Press, Chicago.

Tobin, J. (1980): Asset Accumulation and Economic Activity. University of Chicago Press, Chicago.

Trabandt, M., and H. Uhlig (2009): "How Far Are We From the Slippery Slope? The Laffer Curve Revisited," NBER Working Paper No. 15343.

Velasco, A. (2008): 2008 Annual Public Finance Report. Ministry of Finance Chile, Santiago.

Wallace, N. (1981): "A Modigliani-Miller Theorem for Open-Market Operations," American Economic Review, 71(3), 267-274.

Woodford, M. (1994): "Monetary Policy and Price Level Determinacy in a Cash-inAdvance Economy," Economic Theory, 4(3), 345-380. 
_ (1995): "Price-Level Determinacy Without Control of a Monetary Aggregate," in Carneige-Rochester Conference Series on Public Policy, vol. 43 of Carnegie-Rochester Conference Series on Public Policy, pp. 1-46. North-Holland.

(2001): "Fiscal Requirements for Price Stability," Journal of Money, Credit, and Banking, 33(3), 669-728.

(2003): Interest and Prices: Foundations of a Theory of Monetary Policy. Princeton University Press, Princeton, N.J. 